\title{
PEMANFAATAN OKTIL EUGENILOKSI ETANOAT HASIL SINTESIS SEBAGAI PLASTICIZER MEMBRAN POLIMER CAIR ELEKTRODA SELEKTIF ION
}

\author{
Retno Ariadi Lusiana ${ }^{(1)}$, Dwi Siswanta ${ }^{(2)}$ \\ (1) Jurusan Kimia FMIPA UNDIP Semarang \\ (2) Jurusan Kimia FMIPA Universitas Gadjah Mada
}

\begin{abstract}
ABSTRAK
Dua plasticizer, dibenzil eter (DBE) dan oktil eugeniloksi etanoat (OEE) dipelajari untuk mengetahui kemampuannya dalam membran polimer ESI (Elektroda Selektif Ion) perklorat dengan senyawa aktif TOMA-Cl (tetra oktil metil amonium klorida). Hasil penelitian menunjukkan dari hasil pengukuran terhadap karakteristik ESI perklorat didapatkan bahwa penggunaan DBE memberikan hasil yang lebih baik dibandingkan dengan OEE sebagai plasticizer. Secara umum, interaksi yang terjadi antara fasa membran dengan anion mengikuti kaedah seri Hofmeister.
\end{abstract}

Kata Kunci : OEE, DBE, ESI, plasticizer

\section{ABSTRACT}

Two different plasticizer : DBE and OEE were studied with respect to their applicability for perchlorate selective electrode using trioctylmethyl ammoniumchloride (TOMA-Cl) as an ionophore of the ISE. Results of the measurement of ISE perchlorate performance indicate that the selectivity of the membrane using DBE as plasticizer was better than using OEE. In general, the intercation of membrane phase with anions followed the Hofmeister's series

Key words : OEE, DBE, ESI, plasticizer

\section{PENDAHULUAN}

Perkembangan ilmu pengetahuan dan teknologi telah menghasilkan beberapa metoda analisis baru dengan keunggulan masing-masing. Salah satu metoda analisis yang berkembang pesat dan cukup luas penggunaannya adalah analisis dengan elektroda selektif ion (ESI). Keunggulan metoda ini antara lain bersifat selektif, tidak memerlukan proses pemisahan dan penambahan reagan, serta merupakan metoda analitik yang murah dan sederhana (Siswanta, 1996).

Membran merupakan bagian yang paling penting dari ESI. Penyusun membran polimer cair terdiri atas senyawa aktif (ionofor) sebagai penentu selektivitas, polivinil klorida sebagai matriks pendukung membran, plasticizer sebagai pelarut membran dan pelentur matriks, serta garam-garam organik sebagai katalis. Responden selektivitas ESI terhadap ion logam maupun anion trertentu tergantung pada zat aktif dan komposisi penyusun elektroda lainnya (Attiyat, dkk., 1988).

Selektivitas membran dapat berubah secara signifikan dengan mengubah perbandingan relatif komponen elektroda (Attiyat, dkk., 1988). Menurut Okada, dkk., (1995), plasticizer dan zat organik aditif dapat mempengaruhi selektivitas membran ESI-PVC terutama bila digunakan ionofor dari senyawa asiklik
Dengan memperhatikan struktur senyawa-senyawa yang dapat berfungsi sebagai plasticizer hasil sintesis Eugster, dkk, 1994, yang tersusun atas senyawa ester karboksilat, maka dalam penelitian ini dicoba untuk dapat memanfaatkan ester OEE yang telah berhasil disintesis, sebagai plasticizer membran ESI.

\section{METODE PENELITIAN}

\section{Pembuatan membran}

Membran cair penukar anion dibuat dengan mencampurkan $5 \%$ TOMA-Cl, $62 \%$ plasticizer (OEE,DBE), $33 \%$ matrik PVC dengan berat keseluruhan $150 \mathrm{mg}$. Komposisi lengkap masing-masing membran tertera pada tabel 1. Seluruh campuran dimasukkan ke dalam botol berdiameter $15 \mathrm{~mm}$ dan ditambahkan tetrahidrofuran ( $\pm 3 \mathrm{~mL}$ ), selanjutnya diuapkan dalam temperatur ruang (Siswanta, 1996). Membran yang terbentuk dipotong sehingga diameternya sesuai dengan badan elektroda ( $\pm 12 \mathrm{~mm}$ ). Pengkondisian membran dilakukan minimal selama 24 jam sampai tercapai pembacaan yang stabil dalam larutan $\mathrm{NaClO}_{4} 0,1 \mathrm{M}$. Sel elektrokimia yang digunakan dalam penelitian ini: $\mathrm{Hg} / \mathrm{Hg}_{2} \mathrm{Cl}_{2} / \mathrm{KCl}$ (jenuh)/3MKCl/lar. uji/membran/lar. dalam $/ \mathrm{AgCl} / \mathrm{Ag}$

Tabel 1. Komposisi penyusun membran polimer cair ESI perklorat 


\begin{tabular}{|c|c|c|c|}
\hline Membran & $\begin{array}{c}\text { TOMA-Cl } \\
\text { (\% berat) }\end{array}$ & $\begin{array}{c}\text { Jenis plasticizer } \\
\text { (\% berat) }\end{array}$ & $\begin{array}{c}\text { PVC } \\
\text { (\% berat) }\end{array}$ \\
\hline I & 5 & OEE, 62 & 33 \\
II & 5 & DBE, 62 & 33 \\
\hline
\end{tabular}

Koefisien selektivitas potensiometri, merupakan ukuran besarnya gangguan ion lain (j) terhadap ion utama $\left(\mathrm{ClO}_{4}^{-}\right)$. Penentuan nilai koefisien selektivitas dilakukan dengan metoda larutan terpisah (SSM, separate solution methode), dengan konsentrasi ion utama dan ion pengganggu masing-masing $0,1 \mathrm{M}$ (Buck \& Lindner, 1994). Pengukuran potensial dilakukan terhadap ion perklorat dengan ion pengganggu adalah tiosianat, salisilat, sulfat, nitrat, fluorida, klorida, bromida dan iodida secara terpisah. Selanjutnya nilai koefisien selektivitas ditentukan dengan menggunakan persamaan yang dirumuskan oleh Nicolsky-Einsemen.

Persamaan Nicolsky-Einsemen:

$E=E_{i}{ }^{0}+\frac{2,303 R T}{z_{i} F} \log \left(a+\sum_{i=j} K_{i, j}^{p e t}\left(a_{i}\right)^{z_{i} / z_{j}}\right)$

\section{HASIL PEMBAHASAN}

\section{Karakterisasi ESI Perklorat \\ 1. Koefisien Selektivitas}

Koefisien selektivitas potensiometri merupakan kemampuan elektroda selektif ion untuk membedakan ion utama (i) yang dalam penelitian ini adalah ion perklorat dari ion-ion pengganggu (j). Parameter ini penting untuk mini ion pengganggu Dalam penelitian ini ion pengganggu yang dipelajari adalah ion tiosianat, salisilat, iodida, nitrat, bromida, nitrit, sulfat, klorida, dan bromida. Ion-ion pengganggu ini dipilih karena ukuran ionnya hampir sama sehingga energi hidrasinya hampir sama serta muatannya sama dengan ion mobil $\left(\mathrm{Cl}^{*}\right)$ membran yang dibuat.

Penentuan nilai koefisien selektivitas menggunakan metoda larutan terpisah (SSM), dengan konsentrasi ion utama dan ion pengganggu masing-masing $0,1 \mathrm{M}$ (Buck dan Lindner, 1994; Dwi Siswanta, 1996). Menurut Atikah, 1994, evaluasi terhadap ion penggangu dalam penentuan perklorat diklasifikasikan menjadi 3, yaitu:

(1) jika nilai $\log \mathrm{Cot}_{\mathrm{Cl}_{4, j}^{-}}^{\mathrm{Po}} \leq-2,5$,

ion dikatakan tidak mengganggu,

(2) nilai $-2,5<\log _{\mathrm{ClO}_{4, j}^{-}}^{\mathrm{Pot}} \leq 0$,

ion dikatakan mengganggu

(3) $\operatorname{LogK}_{\mathrm{ClO}_{4}^{-j}}>0$,

ion tersebut di katakan sangat menggangg" .

No. Artikel: JKSA, Vol. V, No. 3, Desember 2002
Nilai selektivitas yang didapatkan dari kedua membran itu dapat dilihat pada tabel 2. Dengan memperhatikan hasil pengukuran dan perhitungan yang dilakukan terhadap nilai koefisien membran ESI, ion-ion dalam ESI perklorat yang diuji Dengan memperhatikan hasil perhitungan terhadap nilai koefisien selektivitas membran ESI didapat diklasifikasikan menjadi dua kelompok, yaitu ion-ion yang mengganggu tiosianat, salisilat, iodida, dan ion yang tidak mengganggu: nitrat, bromida, nitrit, sulfat, fluorida dan klorida. ESI perklorat dengan kedua plasticizer mempunyai urutan seri: $\mathrm{ClO}_{4}>\mathrm{SCN}>\mathrm{Sal}>\mathrm{I}>\mathrm{NO}_{3}>\mathrm{Br}>\mathrm{NO}_{2}>$ $\mathrm{SO}_{4}>\mathrm{F}>\mathrm{Cl}$ yang memenuhi kaedah seri Hofmeister, dengan anion yang hidrofobisistasnya lebih besar akan mudah berada dalam fasa membran yang lipofil.

Berdasar urutan selektivitas terhadap ion pengganggu didapatkan urutan seri sebagai berikut: $\mathrm{ClO}_{4}>\mathrm{SCN}^{-}$ $>\mathrm{Sal}>\mathrm{I}>\mathrm{NO}_{3}>\mathrm{Br}^{-}>\mathrm{NO}_{2}>\mathrm{SO}_{4}{ }^{-}>\mathrm{F}>\mathrm{Cl}^{-}$yang memenuhi kaedah seri Hofmeister, dimanhidrofobisitas. Seperti halnya nilai faktor Nernst, selektivitas dapat berubah secara signifikan dengan mengubah perbandingan dan komposisi relatif komponen membran. Salah satu komponen utama membran elektroda tersebut adalah plasticizer yang fungsi utamanya sebagai pelarut membran dan medium kompleks asosiasi ion TOMA-Cl dan perklorat (Okada dkk., 1995., Attiyat dkk., 1988).

\section{Faktor Nernst}

Faktor ini merupakan salah satu parameter penentu kualitas ESI perklorat. Semakin mendekati nilai faktor Nernst (untuk ion monovalen $\pm 59,2 \mathrm{mV} /$ dekade) maka ESI dikatakan mendekati ideal.

Faktor Nernst merupakan ukuran sensitivitas ESI (Buck dan Lindner, 1994) Faktor Nernst perklorat dihitung dari slope kurva potensial (emf) terhadap logaritma konsentrasi ion perklorat. Pengukuran potensial dilakukan dengan menggunakan kedua membran dan dilakukan pada $\mathrm{pH}$ 7. Pemilihan $\mathrm{pH} 7$ ini berdasarkan penelitian yang dilakukan oleh Selamat, 1999. Nilai faktor Nernst DBE yaitu $-58,6 \mathrm{mV} /$ dekade dengan daerah linear $10^{-4}-10^{-1} \mathrm{M}$ Sedang untuk OEE adalah sebesar $-54,3 \mathrm{mV} /$ dekade dengan daerah linear $10^{-4}-10^{-1} \mathrm{M}$. Dalam membran ESI yang paling menentukan selektivitas dan sensitivitas adalah ionofor yang digunakan dalam membran ESI. Namun demikian je- 
nis plasticizer juga mempengaruhi nilai tersebut berhubungan dengan konstanta stabilitas kompleks asosiasi ion yang terbentuk. (Okada dkk, 1995; Attiyat dkk., 1988, Evans, 1991).

Tabel 2. Nilai faktor Nernst

\begin{tabular}{|c|c|c|}
\hline \multirow{2}{*}[\mathrm{ClO}_{4}]{$(\mathrm{M})$} & \multicolumn{2}{|c|}{ emf $(\mathrm{mV})$} \\
\hline & membran DBE & membran OEE \\
\hline $10^{-6}$ & 506 & 722 \\
\hline $10^{-5}$ & 466 & 714 \\
\hline $10^{-4}$ & 426 & 675 \\
\hline $10^{-3}$ & 373 & 621 \\
\hline $10^{-2}$ & 315 & 568 \\
\hline $10^{-1}$ & 250 & 512 \\
\hline slope & $-58,6$ & $-54,3$ \\
\hline limit deteksi & $10^{-4,6}$ & $10^{-4,6}$ \\
\hline
\end{tabular}

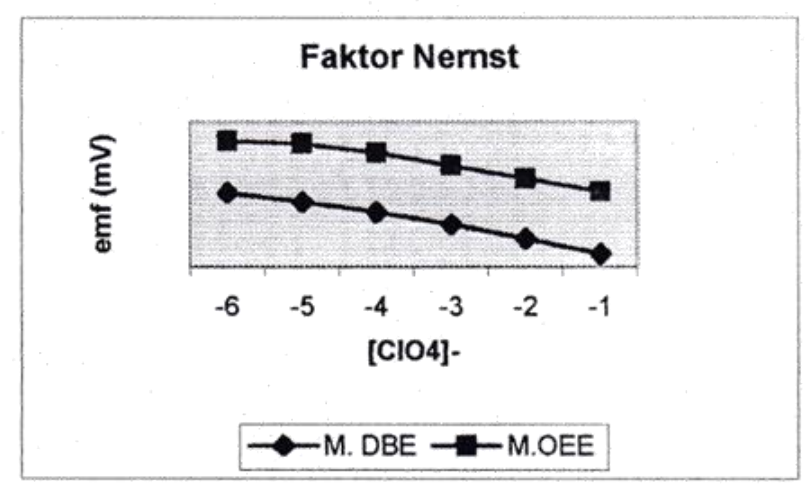

\section{KESIMPULAN}

1. Dengan melihat hasil perhitungan koefisien selektivitas dan faktor nersnt dari kedua plasticizer yang digunakan, didapatkan bahwa DBE memberikan hasil yang lebih baik daripada OEE.

2. Kedua koefisien selektivitas memenuhi kaedah seri Hofmeister.

\section{UCAPAN TERIMA KASIH}

Penulis mengucapkan terima kasih kepada DIKTI karena telah membantu memberi dana untuk terlaksananya penelitian ini.

\section{DAFTAR PUSTAKA}

1. Atikah, 1994, Pembuatan dan Karakterisasi Elekroda Selektif Nitrat Tipe Kawat Terlapis, Tesis, Institut Teknologi Bandung.

2. Attiyat, A.S., Christian, G.O., Hallman, J.L., Bartsch, R.A., 1988, A Comparative Study of the Effect oNitrophenyl Octyl Ether and o-Nitrophenyl Penthyl Ether as Plasticizers on the Response and Selectivity of Carrier - Based Liquid Membrane Ion Selective Elelctrodes, Talanta, 35, 789-794.

3. Buck, R.P., Lindner, E., 1994, IUPAC Recommendations for Nomenclatures of Ion Selective Electrodes, Pure \& Appl. Chem., 66, 2527-2536.
4. Eugster, R., Rozatzin, T, Rusterholz, B., Aebersold, B. Pedrazza, U., Ruegg, D., Schmid, A., Spichiger, U.E., Simon, W., 1994, Plasticizers for Liquid Polymeric Membranes of Ion Selective Chemical Sensors, Anal. Chim. Acta., 289, 1-13.

5. Evans, A., 1991, Potentiometry and Ion Selective Electrodes, John Wiley \& Sons, Chichester.

6. Okada , T., Sugihara, H., Hiratani, K., 1995, Role of Plasticizers on the Characteristic of Poly(vinyl chloride)-membrane Lithium-selective Electrodes Based on Phenantroline Derivatives, Analyst, 120, 2381-2386.

7. Siswanta, D., 1996, Development of Novel Ionophores for Chemical Ion Sensors, Dissertation, Keio Univerciy, Yokohama. 
